\title{
The Vaal River Barrage, South Africa's hardest working water way: an historical contemplation.
}

\author{
Johann Tempelhoff, ${ }^{1}$ VICTOR MUNNIK ${ }^{2}$ and MoRné VILJOEN ${ }^{3}$
}

\begin{abstract}
South Africa's Vaal River is the country's hardest working rivers. It has been instrumental in securing valuable water supplies in the development of the country's economic hub - the Gauteng Province. Since the mid-twentieth century there have been increasing indications of water pollution threatening the storage facility of the Vaal River Barrage, built by the water utility, Rand Water, at the start of the twentieth century.
\end{abstract}

Currently, as a result of a variety of factors, untreated wastewater is posing a severe environmental threat in the Vaal River Barrage Catchment area. In the article attention is given to the origins of pollution and recent events that had the effect of mobilising grassroots anger in civil society with the state of affairs. The article forms part of a transdisciplinary research project that is currently conducted at North-West University's Vaal Triangle campus in Vanderbijlpark.

Keywords: Vaal River Barrage, Rand Water, water pollution, wastewater treatment, river catchment forums, industrial development, water infrastructure, water management.

Disciplines: History, Geography, Public Management and Governance, Environmental Studies, Legal Studies.

As an interpretive practice, contemplation resists stupefaction in the face of the 'big' past and the obscure future; we contemplate a 'living present' through its signs, what stands out, even in obscurity, subject to our estimations and evaluations, our constructions, especially of socially sanctioned passive syntheses or habits - Sande Cohen. ${ }^{4}$

South Africa's Vaal River has played a crucial role in the development of the country. In size, this river that extends over a distance of little more than $1300 \mathrm{~km}$, would be considered, by international standards,

- Paper presented at a symposium, "Streams ran uncontrolled' history, water and engineering" presented at the Delft University of Technology (TUDelft), presented by TUDelft and the International Water History Association (IWHA) on 9 November 2006. The paper is a preliminary report and is representative of some views in civil society. In the next phases of the project, the views of government and the business sector will be incorporated.

1. Water Research Group, School of Basic Sciences, Vaal Triangle Faculty, NorthWest University, Vanderbijlpark, South Africa.

2. Victor Munnik is an independent researcher who actively works with nongovernmental organizations.

3. Morné Viljoen is an attorney, specialising in Environmental and Water Law. He is also a corporate legal advisor for Mittal Steel, South Africa.

4. S Cohen, History out of joint: essays on the use and abuse of history, (The Johns Hopkins University Press, Baltimore, 2006), pp. 105-105. 
to be a medium-sized water way. However, in southern Africa, a region that is water-stressed, the Vaal River is a major role player and has been labelled, with good reason, as one of the hardest working rivers in the country. ${ }^{5}$ The Vaal is a tributary of the Orange River and, unlike most rivers in the country, both rivers flow from the water-rich Drakensberg in the eastern interior to the Atlantic Ocean, on the border between South Africa and Namibia in the west.

\section{Outline and objective}

For the purposes of this discussion we have chosen to take a historical contemplative perspective on the history of the Vaal River. In an attempt to do justice to an extensive field of study, it was considered feasible to concentrate on only one section of the Vaal River - the Vaal River Barrage. A transdisciplinary team of researchers at North-West University, in conjunction with a number of governmental departments, ${ }^{6}$ non-governmental organisations $(\mathrm{NGOs})^{7}$ and representatives of the industrial sector, ${ }^{8}$ are currently busy with a hot spot research project ${ }^{9}$ on the Barrage. It is estimated that the project should be completed by August 2007. ${ }^{10}$

5 This discussion is a continuation of JWN Tempelhoff, "The nature of water and the human culture of territorial appropriation: the Vaal River up to 1956.” Paper present at an international conference "Humankind and Nature and the intersection of culture" presented at Bergendal, Kruger National Park, South Africa, 2006.09.0406. See JWN Tempelhoff, "Water and the human culture of appropriation: the Vaal River up to 1956" in TD The Journal for Transdisciplinary Research in Southern Africa, 2(2), December 2006, pp. 431-452.

6 Participating in the project are: the South African department of water affairs and forestry DWAF), Northern Free State provincial department of nature conservation, and Rand Water.

$7 \quad$ Ecocare, groundWork, Earthlife Africa and SAVE (Save our Vaal Environment). The latter NGO was started in the mid-1990s in an effort to fight developments along the Vaal River Barrage, considered to be detrimental to property values, quality of living and sound principles of conservation. See F van Wyk, An integrated manual for the management, control and protection of the Vaal River Barrage reservoir, ( M.Sc., Rand Afrikaans University [currently University of Johannesburg], 2001), p. 109.

8 Sasol Fuels, Sasolburg.

9 In the Unit for the Cultural Dynamics of Water in Southern Africa, situated at North- West University's Vaal Triangle campus, two hotspot projects have been undertaken since 2005.

10 Funding by the office of the Dean, Vaal Triangle faculty of North-West University, is gratefully acknowledged. Independent funding was also generated within the Water Research Group at NWU. 
The objective is to get the relevant stakeholders to take responsibility in addressing what can be considered as a crisis situation prevailing in the Vaal River Barrage catchment area. In the past year there were two events of pollution ${ }^{11}$ in the Vaal River Barrage. It caused significant fish deaths. ${ }^{12}$ More recently another incident was reported upstream, near Standerton in Mpumalanga. Apart from seriously affecting the quality of life of people in close proximity of the river, it also poses a significant health hazard. There have been warnings that the pollution in the Vaal River Barrage could lead to the outbreak of a water-related epidemic, similar to the typhus outbreak at Delmas in Mpumalanga in $2005 .^{13}$

\section{Origins of the Barrage}

The Vaal River Barrage - essentially a massive reservoir - derives its name from a significant weir in the Vaal River, about $50 \mathrm{~km}$ downstream from Vereeniging. ${ }^{14}$ The barrage was built in 1916-1923 after Rand Water, a bulk water supply utility, founded in 1903, as a result of a partnership alliance between the mining industry and government to provide water to the Witwatersrand where South Africa's gold mining industry was evolving at a rapid rate. The water supply of Johannesburg (founded in 1886) had diminished and pollution posed a health threat. Consequently, Rand Water (previously known as the Rand Water Board) had the responsibility of locating a consistent

11 There are some experts who are of the opinion that the fish kills (particularly the second one) was primarily due to a "natural" process. Sediment churning due to the opening of sluice gates resulting in anoxic conditions is likely to be one of the causes for fish kills - the other being the discharge of untreated waste water.

In 2006 there were two reports of fish deaths in the Vaal River Barrage, and one in the Vaal River near Standerton where the Sterkfontein Dam is situated. Anon., "Vaal Dam 'safe' despite fish deaths" in Business Day, 2006.01.18 at http:// www.businessday.co.za/articles/article.aspx?ID=BD4A140169; E Tempelhoff, "Vrektes nóg 'n terugslag vir Vaal" in Beeld, 2006.07.26 at http://152.111.1.251/ argief/berigte/beeld/2006/07/26/B1/5/etvaal.html;

13 Comment by the consulting engineer, Mr F Kolbe at meeting of the Metsi-a-Lekoa steering committee meeting, Vanderbijlpark, 2006.08.28.

14. For a more comprehensive background on this, see JWN Tempelhoff, "Water and the human culture of appropriation: the Vaal River up to 1956" in TD The Journal for Transdisciplinary Research in Southern Africa, 2(2), December 2006, pp.431452. 
supply of water for what was becoming South Africa's major industrial and financial centre.

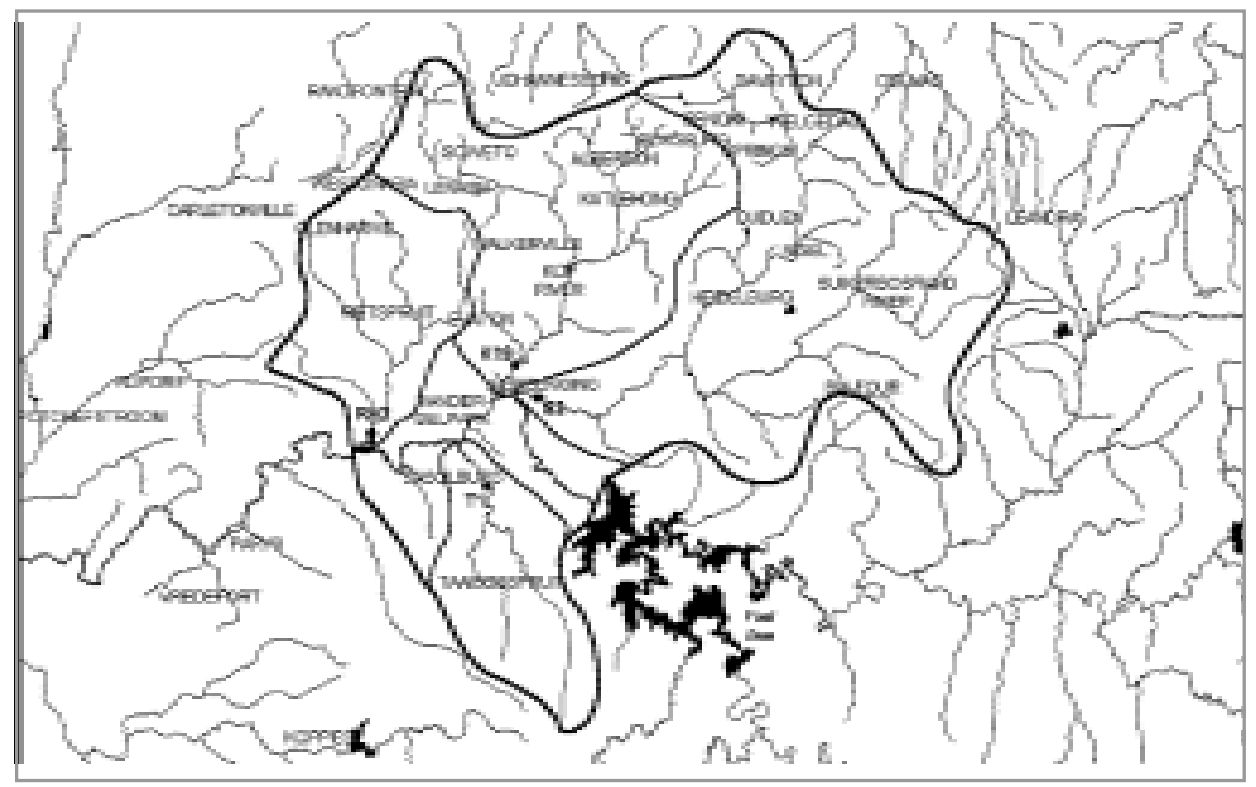

Illustration (Map) 1: The Vaal River Barrage Catchment. ${ }^{15}$

Today the Vaal River Barrage catchment covers a surface area of about $900 \mathrm{~km}^{2}$. It is a mere 4,5 per cent of the total Vaal River catchment surface area. What makes this catchment different but is the fact that it is part and parcel of the Gauteng Province, the most densely populated area in South Africa. An estimated population of about 10 million people are resident in the catchment in which there are 13600 wet industries, more than 20 wastewater treatment plants and a number of mines that invariably tend to contribute to pollution of fresh water supplies. ${ }^{16}$

15 Map in F van Wyk, An integrated manual for the management, control and protection of the Vaal River Barrage reservoir, p. 16. Note: Although most readers will understand what is meant, it is technically incorrect to call this catchment the "Vaal River Barrage Catchment". The entire Vaal Dam catchment also forms part of the Barrage catchment. For the purposes of this discussion, we mean the Vaal River Barrage catchment, excluding upstream Vaal Dam.

16 F van Wyk, An integrated manual for the management, control and protection of the Vaal River Barrage reservoir, pp. 5, 16. 


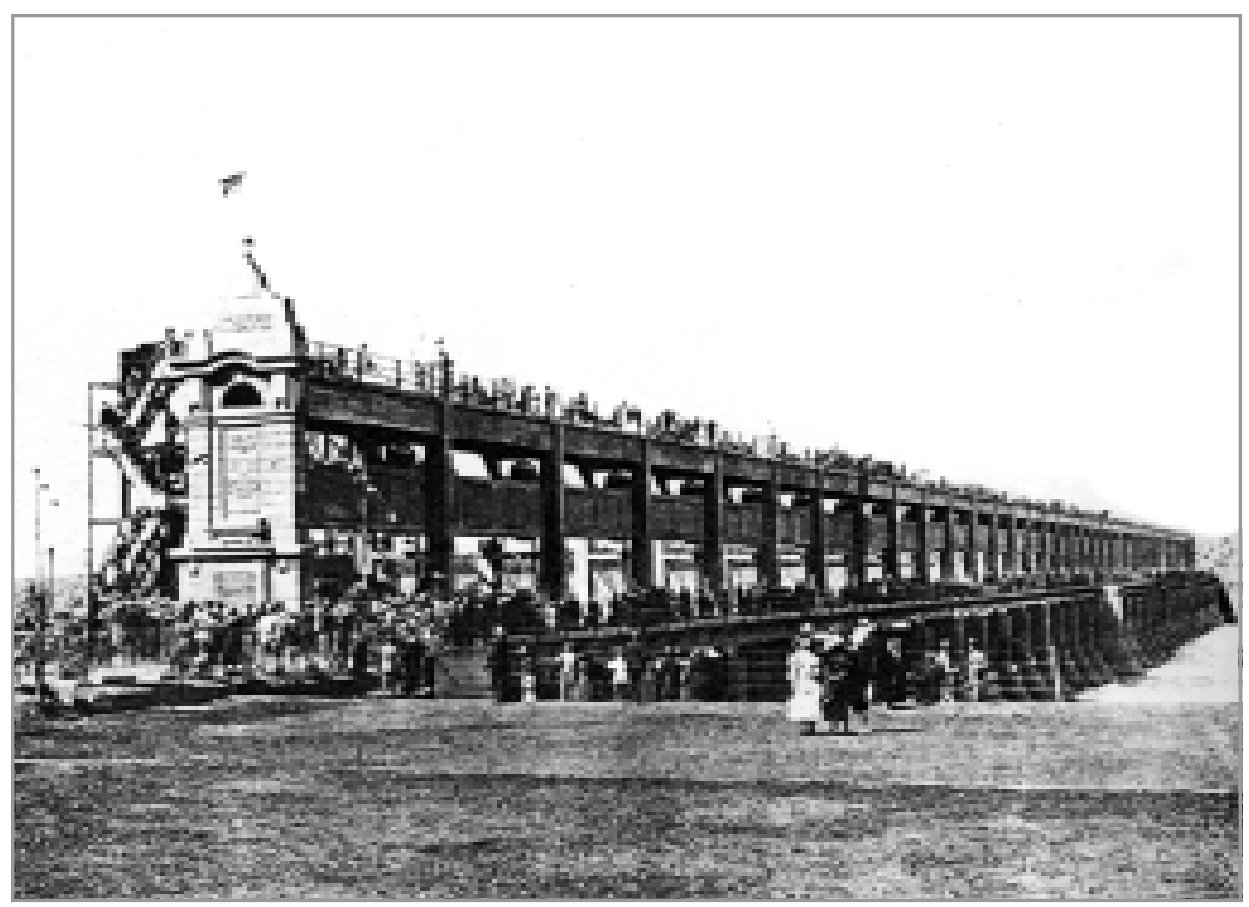

\section{Illustration 2: The Barrage in the Vaal River at the time of its inauguration in 1923. ${ }^{17}$}

\section{Providing water to the Witwatersrand}

At the time of its completion in 1922 the Barrage was able to provide in the essential demand for water on the Witwatersrand. However, indications were that also this source of supply would soon be insufficient. The mining industry had underestimated the potential life of the gold mines of the Witwatersrand. Consequently, the development phase in which the Barrage had been built, made provision for a slightly larger than average urban environment on the Witwatersrand. The purification plant of the Barrage was situated at Vereeniging, a coal mining town, founded in 1892. From there the water was pumped against a head of some $200 \mathrm{~m}$ over a distance of $70 \mathrm{~km}$ to the Witwatersrand. ${ }^{18}$

17 Source: Rand Water Archives, Rietvlei

18 JWN Tempelhoff, "Time and the river: observations on the Vaal River as source of water to the Witwatersrand 1903-24" Historia 46(1), May 2001, pp. 247-70. 
Then, in 1932 the government, in an effort to boost the agricultural sector of the country initiated the Vaal Dam project, about $40 \mathrm{~km}$ upstream from Vereeniging in the Vaal River. At the time of its completion in 1938 the Vaal Dam provided water to the Vaalharts irrigation scheme, near Warrenton in the Northern Cape Province. This was at the time of its completion the largest irrigation scheme in the southern hemisphere. A substantial portion of the storage capacity of the dam was allocated to Rand Water for distribution to the urban settlements and industrial sector on the Witwatersrand. ${ }^{19}$

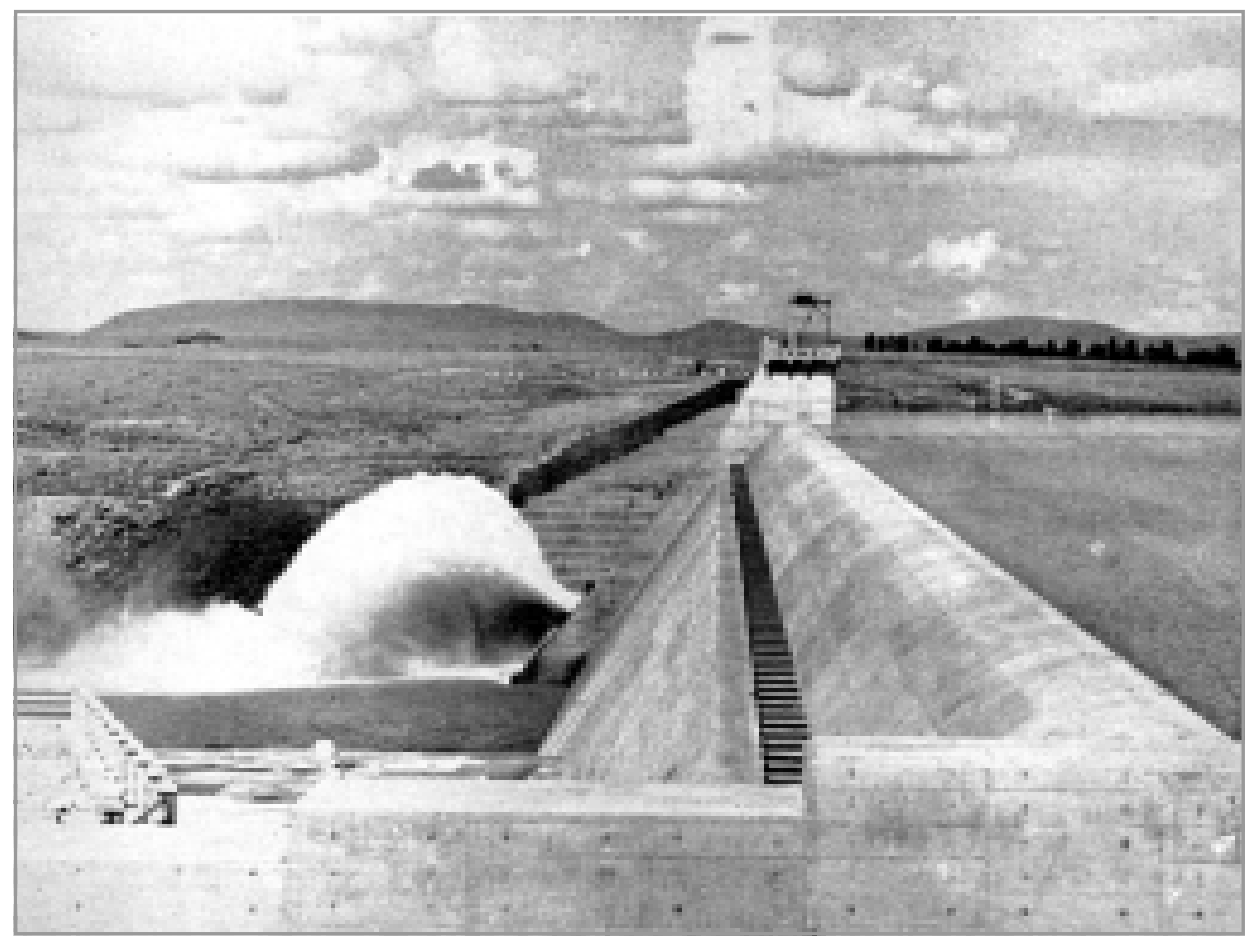

Illustration 3: The Vaal Dam at the time of its completion in $1938 .^{20}$

19 JWN Tempelhoff, "Omgewingslagoffers of armblankes? Water en welvaartskepping in die era van Hertzog (1924-1939),", Genl. J.B.M. Hertzoggedenklesing, XXXV, Pretoria, 21 September 2006 (Suid-Afrikaanse Akademie vir Wetenskap en Kuns, Pretoria) pp. 26-28.

20 Source: Rand Water Archives, Rietvlei. 


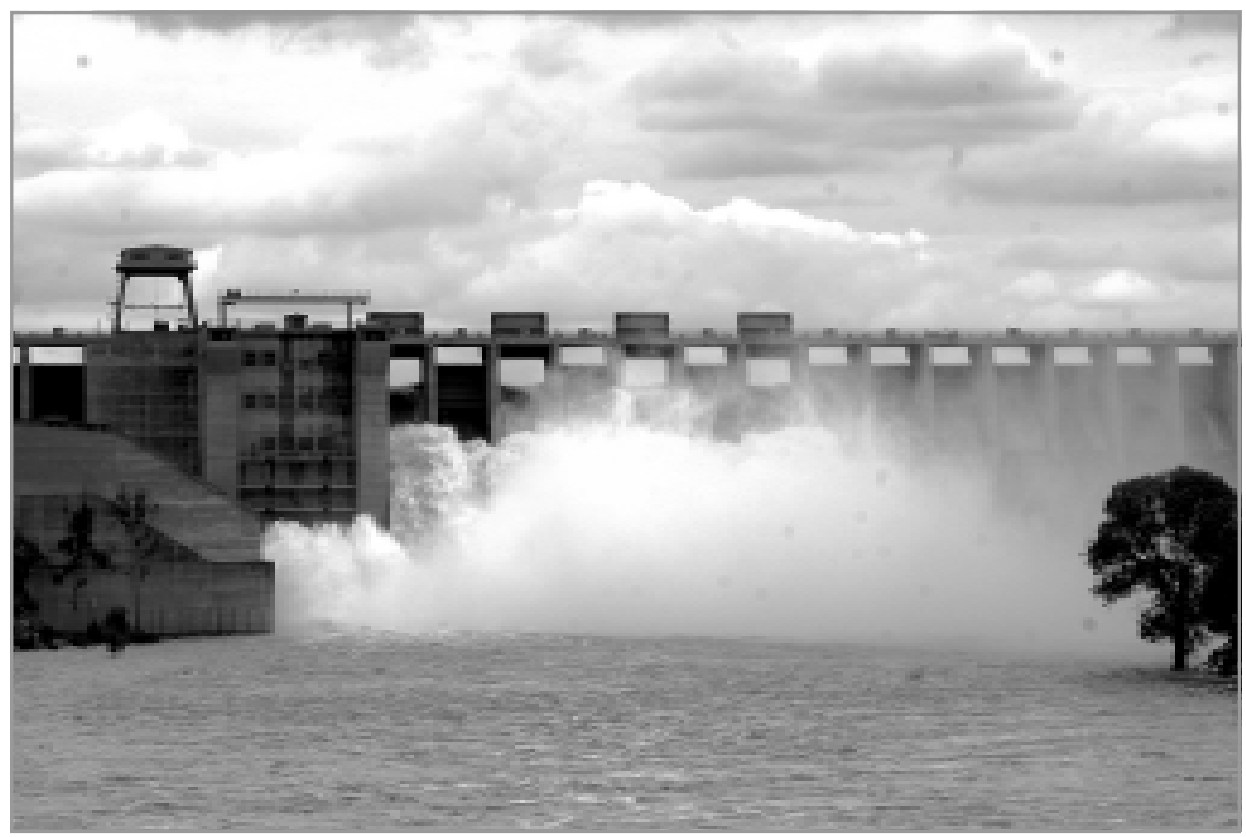

Illustration 4: The Vaal Dam at the time of the floods of $2006 .^{21}$

\section{The Zuikerbosch water treatment works}

In the 1950 s, as a result of an increasing threat of pollution in the Barrage and a greater demand for water, ${ }^{22}$ Rand Water built the Zuikerbosch purification plant just above the Blesbokspruit in the Barrage area. This massive plant, with substantial capacity for expansion, enabled Rand Water to provide in the ever-increasing demand for water to the Witwatersrand, but also to Vanderbijlpark and Sasolburg, two urban settlements that had been founded on the banks of the Vaal River in the Barrage area.

Vanderbijlpark, proclaimed in $1949,{ }^{23}$ was to be the home of a massive flat steel producing plant of the parastatal Iron and Steel Corporation

21 Photograph Johann WN Tempelhoff.

22 RJ Laburn, "Problems resulting from the discharge of sewage effluents and industrial effluents from the Witwatersrand into the Vaal River Barrage" (Printed copy of a paper presented at a symposium of the Institute of Water Pollution Control held in East London, May 12968), p. 2.

For details on the works of Iscor and the implication for the water supply, see Rand Water Archives (Rietvlei), RWA File 985, F. Kanthack, Johannesburg - Chief engineer Rand Water Board, Johannesburg, 1942.11.04. 
of South Africa (Iscor), founded in 1925. ${ }^{24}$ Sasolburg, founded in 1950 on the Orange Free State side of the Vaal River Barrage, was home to the pioneering industry responsible for manufacturing synthetic fuel from coal. Sasol was also initiated by the government. ${ }^{25}$ In line with the policies of segregation (1905-1948) and apartheid (19481990) African townships such as Sharpeville (1942), ${ }^{26}$ Bophelong (1955), Boipatong (1955), Sebokeng (1965) and Zamdela (1976), had been established. ${ }^{27}$

By mid-century the Vaal Triangle, in which the Vaal River Barrage was situated, had become an important industrial centre of South Africa. Coal mining activities and the availability of water, had made the region a major supplier of electricity and strategic industrial production. It was in this period that the problem of water pollution started featuring prominently in engineering strategies to solve waterrelated problems. ${ }^{28}$

In the 1960s, as a result of South Africa's economic growth, more pressure was brought to bear on the Vaal River Barrage. ${ }^{29}$ At the time, one of the most severe droughts of the century prevailed in the country. Rand Water, in an attempt to deal with the greater demand for water supplies, was prominent, in conjunction with local authorities, for promoting strategies of water restrictions in its service supply area. This proved to be successful over the short term. However, water engineers and managers were more than aware that the demand for water would increase in the near future.

24 Iron and steel industry Act, No. 11 of 1928 in J.M. Murray et. al., The Union Statutes 1910-1947: Classified and annotated reprint, Vol. 12, (Government Printer, Pretoria, 1952), pp. 127-48.

25 J. Meintjes, Sasol 1950-1975, (Tafelberg, Cape Town, 1975), Chapters 2, 4, 5 and 6; For more information on the history of Sasol, see P Wessels, Crescendo tot sukses: Sasol 1975-1987, (Human \& Rousseau, Kaapstad en Johannesburg, 1990); J Collings, Mind over matter: The Sasol story: a half century of technological innovation, (Sasol, Johannesburg, 2002).

26 M Willemse, Die vestiging en uitbouing van munisipale bestuur en voorstedelike ontwikkeling in Vereeniging tot 1992, (MA, PUCHO, (currently NWU), 1999), pp. 141-145.

27 H Mashabbela, Townships of the PWV, (South African Institute of Race Relations, Johannesburg, 1988), pp. 37-40; 41-44; 127-134, 178-181;

28 RJ Laburn, "Problems resulting from the discharge of sewage effluents and industrial effluents from the Witwatersrand into the Vaal River Barrage" (Printed copy of a paper presented at a symposium of the Institute of Water Pollution Control held in East London, May 1968), pp. 1-3.

29 RJ Laburn, "Problems resulting from the discharge of sewage effluents and industrial effluents from the Witwatersrand into the Vaal River Barrage" (Printed copy of a paper presented at a symposium of the Institute of Water Pollution Control held in East London, May 12968), pp. 2-8. 


\section{The fuel crisis and the Tukhela scheme}

Whilst it was possible to curb domestic consumption, the need for water in the industrial sector was at a premium. The year 1973 saw the era of the first fuel crisis. This sparked off an initiative by government to launch the Tukhela transfer scheme. This, one of the major South African civil engineering projects of the decade, was instrumental in supplying water to the Eastern Transvaal (currently Mpumalanga Province) where the second synthetic fuel project of Sasol was started at Secunda. Part of the project was the construction of the Sterkfontein Dam near Phuthaditjaba that served as an additional storage facility to the Vaal Dam. Both these facilities were situated upstream of the Vaal River Barrage. ${ }^{30}$

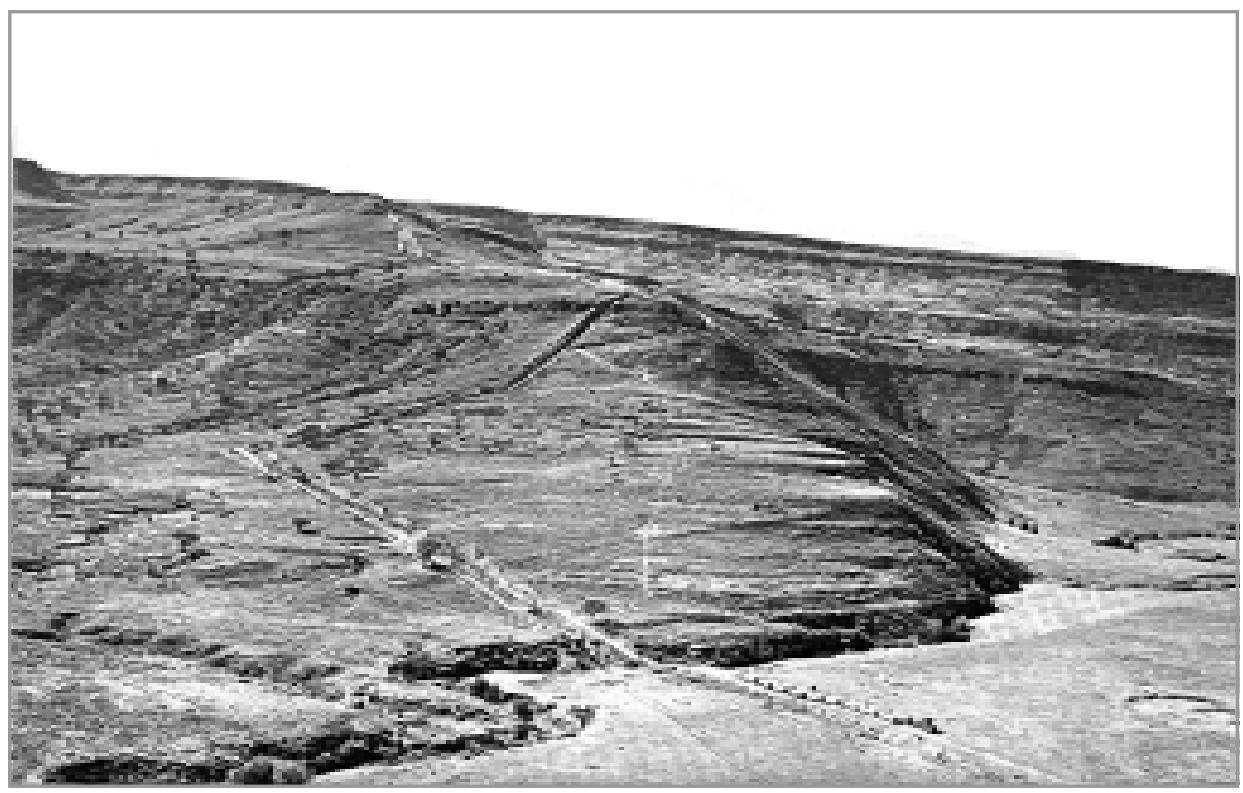

Illustration 5: The Tukhela water transfer scheme under construction in the 1970s. ${ }^{31}$

30 Anon., "The role of the Rand Water Board in the Tukhela Vaal government water project" in Water, 1974, p. 6; Oral information from the late Mr Robert James (Bob) Laburn, Rand Water Headquarters, 2002.10.07; Rand Water Archives, Rietvlei, Africana collection: J.L. Gardiner, "Some historical aspects of the water supply to the PWVS complex", (undated manuscript); RSA, Department of Water Affairs and Forestry, Vaal River: life-blood of a nation, (CTP, Cape Town, 1993).

Source: Rand Water Archives, Rietvlei. 
In the 1980s the increasing demand for water, saw the longest drought period in the Gauteng region, since the beginning of the twentieth century. Comprehensive measures were introduced to find additional sources of water. Limited attention was given to recycling water and integrating it extensively with the standard potable supply of water, as was the case of Windhoek in Namibia, where some groundbreaking work had been made in the field by the early 1970s. Windhoek was the first urban centre in southern Africa to rely primarily on recycled water. ${ }^{32}$ In South Africa planners reckoned a similar strategy would be a too costly operation.

Instead, the South African government in 1986 concluded an agreement with the government of Lesotho for the development of the Lesotho Highlands Water Project (LHWP) - a mega water scheme that had already been outlined in the 1950s, but was unfeasible as a result of the high costs. By the 1980s this project was considered essential for the sustained growth of the Gauteng region. ${ }^{33}$ It was a time when the country saw the gradual de facto decline of the apartheid policies of the government, and attempts at the creation of local government structures for African townships. The local governance project was not very successful, but the idea of regional development, formed the basis for development plans that would get under way in the next decade. The LHWP was an important element in regional planning. Modernising the urban environment and its infrastructure for all the country's people implied that substantial water supplies had to be readily available.

\section{Pollution threat}

By the mid-1980s there was increasing evidence of waste water pollution in the Vaal River Barrage. ${ }^{34}$ The 'bush war' of the South African government against the South West African Peoples' Organisation (Swapo) in Namibia and the African National Congres' (ANC) freedom fighters, on the country's borders, was reaching a peak. Internationally, South Africa had been effectively isolated from the outside world and was increasingly dependent on its own industries for armaments. Industries in the Vaal Triangle now formed an

32 JWN Tempelhoff, The substance of ubiquity: Rand Water 1903-2003, (Kleio Publishers, Vanderbilpark, 2003), pp. 307-308.

33 Ibid., pp. 393-397.

34 D Hallowes and V Munnik, The groundwork report 2006: Poisoned spaces manufacturing wealth, producing poverty, (groundWork, Pietermaritzburg, 2006), pp. 101-102. 
important part of the government's attempts to provide in the need for arms and ammunition. ${ }^{35}$ Production demands placed extreme pressure on local industries. In the process environmental concerns were placed on the backburner, in the interest of what was popularly communicated in the media as the fight against communism.

The international collapse of the East-West divide in 1989 and the subsequent relinquishment in South Africa of power by the National Party-controlled government, in favour of a multi-racial democratic dispensation in 1994, saw industries in the Vaal Triangle region collapse into a phase of post-industrial lethargy. Major industrial concerns, such as the Union Steel Corporation (USCO), started transforming by selling off its plants in Vereeniging to the parastatal South African Iron and Steel Corporation (ISCOR). ISCOR itself, at the time, started with a major privatision programme. Conditions of unemployment, especially in the unskilled labour sector, affected more than 50 per cent of the Vaal Triangle's economically active population by the late 1990s. In 2004 a comprehensive analysis of growth in the regional economy suggested that by 2015 as much as 60 per cent of the region's economically active population could be unemployed. ${ }^{36}$

One outcome of the post-industrial phase in which the Vaal Triangle economy found itself was that industrial activities now came under the looking glass. Civil society, in conjunction with government, started asserting pressure on industry to reduce air and water pollution. The water pollution crisis that had been lurking since the 1960 s was addressed after a concerned environmental scientist, turned whistleblower and made disclosures of how the industry had polluted the ground water supplies in parts of the Vaal Triangle. ${ }^{37}$ Moreover, this pollution, which had been at the order of the day for years, had severely affected the Vaal River Barrage. 1974-1994, (Unpublished PhD, PUCHO (currently NWU), 2002), pp. 333-354.

36 TJC Slabbert, An investigation into the state of affairs and sustainability of the Emfuleni economy (D. Comm. University of Pretoria, 2004). The economic growth of South Africa has, in recent months exceeded all expectations, but the indications are that the problem of unemployment in the Vaal Triangle has not been reduced by any measure comparable with employment trends in the more densely populated Elizabeth-Uitenhage, Durban-Pinetown and Johannesburg-Midrand-Pretoria.

37 JE and JWN Tempelhoff, "The community, industry and the quest for a clean Vaal River 1997 in S Hood-Washington, P Rosier and H goodall (eds.), The poisoned well: global memories of environmental injustice, (Lexington Publishers USA, 2006), pp. 378-407. 
At the same time there were numerous collapses of sanitary services in parts of Gauteng. In the late 1980s the government had informally lifted urban influx control. Many thousands of people from the rural areas of South Africa and the neighbouring states started drifting to the Witwatersrand where they first sought accommodation in existing African townships. When these were too crowded, they resorted to illegally squatting on open lands near urban centres, establishing a vast array of informal housing settlements. This state of affairs caused a housing crisis. It also contributed to a major sanitary crisis. Many of the informal settlements were situated in the catchment areas of the Klip ${ }^{38}$ and the Suikerbosrand rivers - both tributaries of the Vaal River in the Barrage catchment.

In an effort to address the crisis a number of local authorities joined forces, and along with government departments and private sector support, established the East Rand Water Care Company (ERWAT) in 1992 , with the responsibility of treating waste-water of a population of more than 3,5 million people in the eastern parts of Gauteng's Ekhuruleni Metropolitan Council area. ${ }^{39}$ At the time of its establishment there were annually as many as 6105 sewer blockages in parts of the Vaal River Barrage catchment area. ${ }^{40}$

A major setback for the sanitary services of the local authorities in the Vaal River Barrage catchment area was the fact that, in the transition to a new democratic dispensation, there was a rapid changeover in the structure of municipal services. White officials sought employment in the private sector, or they went on early retirement. In the process valuable human resources, with lots of experience, was lost. They were mostly technical experts responsible for the maintenance and upkeep of old sewerage works that were prone to collapse in the face of an extraordinary increase in the population of the Witwatersrand. ${ }^{41}$

38 The Klip River is responsible for 90 per cent of the flow of the Vaal River Barrage. See $\mathrm{F}$ van Wyk, An integrated manual for the management, control and protection of the Vaal River Barrage reservoir, p. 6.

39 At present the company is responsible for treating $550 \mathrm{Ml}$ of water daily. Anon., "Company profile - About ERWAT" in East Rand Water Care Company at http:// www.erwat.co.za/general/general.asp?ID=9 (Accessed on 2006.10.29).

$40 \quad \mathrm{~F}$ van Wyk, An integrated manual for the management, control and protection of the Vaal River Barrage reservoir, pp. 5-6.

41 P de Bruin, "SA se 'vuil en vieslike water' kan glo verder versleg" in Beeld, 2003.01.23, p. 4; E Tempelhoff, "Riool kos raad glo R500 000: pomp breek 3de keer" in Beeld, 1999.07.21, p. 14; E Tempelhoff, "Inwoners 'op tydbom' oor riool in rivier" in Beeld, 1999.07.22, p. 6. 


\section{Changed role of Rand Water}

The ongoing environmental crisis of the Vaal River Barrage was monitored by Rand Water which had, up to the passing of the new National Water Act, No 36 of $1998,{ }^{42}$ been responsible for managing the Vaal River Barrage.

Rand Water's power to intervene depended on two sources: its legal prerogative (via the Rand Water Statutes and its status as riparian owner) as well as its extensive water quality monitoring network and database. It had the legal power to cut off water supply to industries on suspicion of pollution, and to take polluters to court. This power was used more as a threat than an actual intervention, because Rand Water preferred to explain the consequences of pollution to offenders, and encourage them to clean up their act. Threats of exposing polluters in the media often had the desired effect. At the time pollution was not treated as an issue that required public awareness and participation. Rand Water was also literally the owner of the water between the Lethabo Weir and the Vaal Barrage. This was because the owner of the riparian land owned the water in the river, and Rand Water had purchased continuous strips of land all along the river. This situation changed with the new National Water Act, which returned ownership of water to the South African people, held in custodianship by the state in the form of the department of water affairs and forestry. Consequently Rand Water had to reposition its water protection programme. ${ }^{43}$

It found the space to do so in a new system of catchment management forums, to which Rand Water has lent considerable support. The philosophy of catchment based management had been developed as part of a water policy process since 1994. But it was a water crisis in 1996 that led, quite independently, to the establishment of the first catchment management forum in the Upper Vaal - the Blesbokspruit. The Blesbokspruit is home to a Ramsar wetland, as well as the Grootvlei goldmine with acid drainage. Grootvlei was the last gold mine in the region. Its neighbours had all closed operations earlier. When they closed down, they also stopped pumping (acid) mine water out of their shafts. This water then started draining into Grootvlei's water. The volumes were overwhelming and the mine simply let it run into the river untreated. This caused a public outcry. Then DWAF's minister,

42 Republic of South Africa, National Water Act, No. 36 of 1998 at http://www.elaw.org/ assets/pdf/south.africa.water.act.1998.pdf. Signed by the President on 1998.08.20.

43 This section is based on: an interview, by Victor Munnik, with Pieter van Eeden, chairperson of the Klip Catchment Forum, Francois van Wyk of Rand Water, 1 Nov 2006; direct observations of the Upper Vaal forum meetings; and browsing the website www.reservoir.co.za.

TD, 3(1), July 2007, pp. 107-133. 
Prof. Kader Asmal, revoked the mine's permit to operate. At the time the mine's management pointed out that it would have to retrench its 3000 workers, with dire effects on the local economy. Asmal reissued its permit, but with strict conditions and the requirement that a forum of all stakeholders be formed for the Blesbokspruit catchment. This forum was the model for subsequent forums in the industrialised Upper Vaal: the Klip (home of many Witwatersrand gold mines and urban Johannesburg), the Rietspruit (where Iscor/Mittal are the major industries) and the Leeu-Taai (location of the Sasol petrochemical complex and other industrial facilities). Together these four catchments determine the water quality of the Barrage. The Vaal River Barrage's water quality is finally determined by the release from the Vaal Dam.

Rand Water still had its other very important source of power monitoring. It soon noticed that its monitoring was by far the most complete - and had historical depth going back 50 years or more. Its monitoring carries authority in the forums, and is the main instrument to encourage DWAF officials to take action against polluters. DWAF does monitoring, so do the larger municipalities, and some mines and industries do self-monitoring. The forums have established guidelines for water quality, clustered into four groups:

The first - phosphates, ammonia, nitrates and faecal coliforms indicate pollution from sewage. The second - sulphates, chlorides and heavy metals - indicate pollution from mines (the acidity is also an indicator of acid mine drainage). The third - fluorides, chemical oxygen demand and other indicators - shows industrial pollution. The overall toxicity of the water - the fourth group - is tested on waterfleas and guppies (fish). But the monitoring is complex and there are many loopholes. Polluters can, for example, flush pollutants into the river in between testing times (that are regular and known), and escape detection. And turning monitoring data into forensic (criminal) evidence requires exacting protocols (e.g. the presence of a certifying policeman when samples are taken and sealed). Identifying causal mechanisms for longer trends requires extra analytical work, for which resources are only intermittently available.

How well do the forums function? Dr Pieter van Eeden, the former Iscor whistleblower, referred to above, and chairperson of the Klip River Forum, sees the forums as places of accountability. They are open to the public and public groups, industries and regulators raise and discuss issues. But it only works as an accountability mechanism when the polluters are willing to attend the forum. Because the forum is voluntary, they have the option of saying "we only have to comply with the conditions of our water use licences and we don't have to care about your water fleas dying", says Van Eeden with some exasperation. The reward for a company that does attend the forum 
and improve its water quality care, is a reputation for environmental responsibility. That can be worth a lot, says Van Eeden. "Many industries do see the point and understand that proper environmental care can save them money," says Van Wyk.

DWAF has been criticised for playing a minimal role in providing resources. Also the department's apparent lethargy in responding rapidly to crises in the catchment has been criticised. ${ }^{44}$ This makes the operations of the forums vulnerable, because the quarterly forums are hosted by participants, often industries. If they withdraw from the forum, the meeting place can fall away too. In a recent instance, a big player withdrew because information it had tabled at the forum, was used in a court case against it.

It is noticeable that a number of committed water professionals attend the forums which range from 10 to 40 people per meeting. But public participation could be more extensive, says van Eeden. Municipal councillors soon become bored with attending. Some industries attend only when they need to push through a license application and vanish when they have achieved it. Some community groups - usually from the better off communities - attend and comment regularly. Poorer communities are badly represented. Participation requires organisation, financial resources (e.g. for transport) and access to information. For communities in informal settlements (who are paradoxically most directly affected by water quality issues, these conditions remain unmet. And should they make it to a meeting, the chances of effective and informed participation, seem remote. Despite efforts to provide information, mostly on a dedicated website, the information is not easy to understand at first sight, because a familiarity with the guidelines and function of the indicators is required. Improving information provision, for example through newsletters, once again raises budget obstacles.

The reality of the catchment forums reflects the reality of water quality regulation in South Africa. The "polluter pays" principle does not apply. The current or potential victims of pollution are expected to carry the costs of regulating pollution on a voluntary basis. If they cannot afford it, they remain excluded. Self-regulation remains the norm in practice. Polluters, or potential polluters, can choose whether they attend the forums or not. They have to be "kept on board". This opens the option for polluters to withdraw from forums, or to threaten to withdraw, and enables them to avoid censure or robust discussion of their

44 In respect of a recent spate of fish deaths in the Vaal River Barrage, see the email correspondence between DWAF officials and concerned parties M Viljoen - M Lintnaar-Strauss (DWAF), 2006.10.02; M Fourie (DWAF) - B Fourie, 2006.10. 04; M Viljoen - M Fourie (DWAF), 2006.10.04. 
pollution. Placing the burden on the polluted to keep the forums going, compromises their ability to protect themselves against pollution.

Despite their problems, the forum meetings provide fascinating insights into the realities of water quality challenges in the Upper Vaal. They also provide unique opportunities for information exchange, networking and building personal understanding between individuals who would otherwise remain opponents with little sympathy or understanding for each other's concerns and constraints. Rand Water's Van Wyk expects the forums to remain permanent features of water regulation, because of their local character and participation.

It is also clear that organised civil society will have to play a strong role to ensure that reasonable health standards are maintained. This role is increasingly taken up but, at the same time, it is the wellresourced who can do it, and those who with the least resources (and the most at risk) who are, for all practical purposes, excluded. It is really up to the DWAF to change this and provide a sustainable resource base for the forums.

\section{Recent responses to crisis conditions}

In recent years the residents of valuable properties along the Klip River and Vaal River Barrage have played an important role. It is they who have complained of the deteriorating state of affairs of the water realm. For property owners who had been resident on the banks of the water ways for many years, there was personal trauma as their quality of life deteriorated. ${ }^{45}$ There were increasing threats of legal steps against local authorities that did not meet their responsibilities and in some areas some concerned resident groups started resorting to activist measures. ${ }^{46}$

45 For a detailed investigation of the manner in which the pollution of the Klip River affected residents of houses see EP de Crom, Die impak van ekologiese versteurings op die welstand van die individu: 'n narratiewe ondersoek (MA, PUCHE (currently North-West University), 2000).

46 A Dreyer, "Cholera-gevaarligte in Gauteng"in Beeld, 2000.10.13, p. 5. 


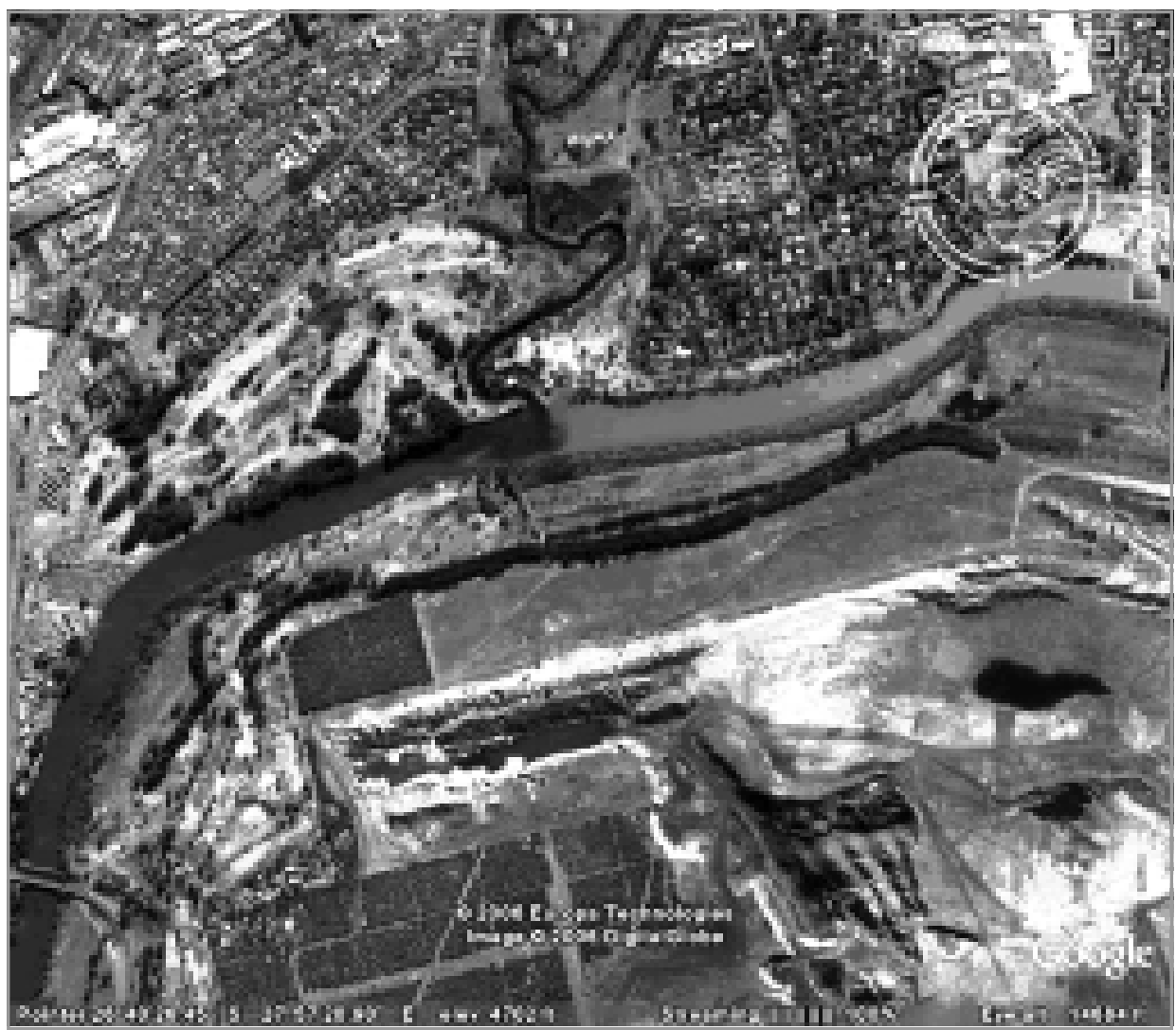

\section{Illustration 6: Example of waste water flowing down the Klip River into the Vaal River Barrage. ${ }^{47}$}

The pressure on local authorities and industry increased shortly after the turn of the new millennium when property prices in South Africa shot up. The banks of the Vaal River Barrage and Loch Vaal became desirable localities for people who wanted weekend houses in golf estate developments or large housing complexes on the river front. ${ }^{48}$ Developers and residents had significant muscle. They had been able to prevent coal mining activities from taking place on the Free State

$47 \quad$ Illustration provided by an NGO that preferred to remain anonymous.

48 D Fielding, "Living by the water's edge" in Business Day, 2004.02.20. at http:// www.businessday.co.za/Articles/TarkArticle.aspx?ID=953048; Business Day Reporter, "New golf estate tees off on the Vaal" in Business Day, 2004/05/05 at http://www.businessday.co.za/Articles/TarkArticle.aspx? ID=1029792; N Wilson, "New R4bn Vaal project a golfing, skiing paradise" in Business Day, 2005/04/20 at http://www.businessday.co.za/Articles/Tark Article.aspx?ID=1430317; 
side of the Vaal River Barrage. ${ }^{49}$ They were consistent in their vociferous criticism of the way in which local authorities and governmental departments were seeing to the health of the river.

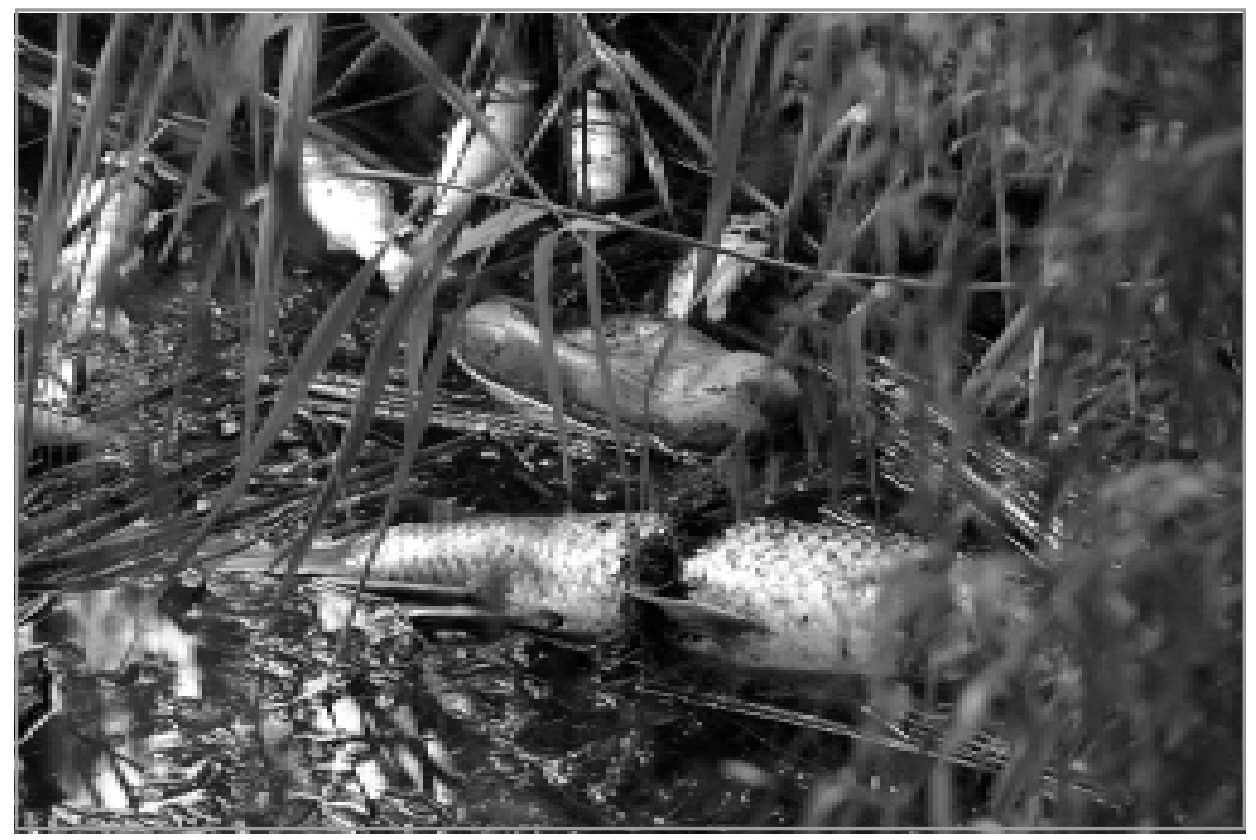

Illustration 7: Thousands of fish died in January 2006 as a result of sewage effluent flowing into the Vaal River Barrage. ${ }^{50}$

Increasingly there has been a demand for the restoration of the environment of the Vaal River Barrage to the extent that it would be conducive to leisure activities generally associated with riverscapes in a water-stressed country. The ire of civil society was consistently raised by the pococurante attitude of the local authorities responsible for water and sanitation services.

At the time of the first spate of fish deaths in mid-January 2006 the blame was squarely placed on the shoulders of untreated sewage flowing into the Vaal River. It was surmised that, as a result of the heavy rains sewage had flowed down the Klip River and into the Vaal River Barrage. Further downstream, in the Middle Vaal, there had

49 Editorial comment, "Rand Water concerned about mining plans" in Business Day, 1998.01.06.; E Tempelhoff, "Sasol gaan nie meer voort met steenkoolmyn aan Vaalrivier" in Beeld, 1999.01.22 at http://152.111.1.251/argief/berigte/beeld/ 1999/10/22/1/10.html.

50 Photograph: Johann WN Tempelhoff 2006. 
also been a spate of fish deaths, but this was caused by untreated sewage that entered the Vaal via the Schoonspruit in North West Province. It was at the end of the festive period and anglers were upset by the large number of deaths of indigenous and endangered yellow fish (Labeobarbus kimberleyensis and Labeobarbus aeneus). ${ }^{51}$

The event came at a time when there was considerable introspection in local government circles about the treatment of waste water in the Vaal River Barrage. In an effort to cope with the crisis the Emfuleni local municipality in 2005, with the assistance of the department of water affairs and forestry (DWAF), appointed a retired engineer as consultant to do a survey on its waste water treatment system. $\mathrm{Mr}$ Fred Kolbe's report was completed in December 2005. Over the past half century some 50 sewage pump stations were built for pumping treated waste water into the Vaal River barrage. Amongst the major problems identified by Kolbe were:

It was problematical to manage the three water treatment plants in the municipal area as a result of management constraints.

Municipal budget allocations were inadequate for the maintenance of the two (Rietspruit and Leeuwkuil) of the three (third Sebokeng) treatment plants. This resulted in equipment failing and producing inferior effluent.

There were also problems in respect of the work ethic amongst people employed by Emfuleni for the maintenance of the treatment plants. ${ }^{52}$

In an effort to deal with the problem the local authority created Metsia-Lekoa, an independent water business and consolidated the operations of the local authority's wastewater treatment system. It was estimated that a total of R26,46 million was necessary for improving the existing infrastructure. It was recommended that over the long-term an amount of R345 million be made available to comprehensively address the existing problem. ${ }^{53}$ For the interim, emergency measures were implemented to get pump stations and treatment plants in the municipal area into a working condition. Officials of DWAF, in conjunction with the local authority, and a

51 E Tempelhoff, "Ekologiese ramp tref Vaalrivier: generasies geelvisse uitgewis" in Beeld, 2006.01.17, p. 1; Media release by K Wallington, "Fish kills on the Vaal River, what are the Facts? The Yellow Fish Working Grolup seeks to bring some clarity (2006.01.21) at

www.yellowsonfly.com/uploads/YWG_release_Vaalpollution_250106.pdf-.

52 F Kolbe, Discharges to the Vaal River. Report on mitigating measures: TS2 1: Emfuleni restructuring grant (Department of water affairs and forestry, Pretoria, 2005), p. 14.

53 F Kolbe, Discharges to the Vaal River. Report on mitigating measures: TS2 1: Emfuleni restructuring grant (Department of water affairs and forestry, Pretoria, 2005), p. 6.

TD, 3(1), July 2007, pp. 107-133. 
number of stakeholders started attending regular meetings to discuss progress.

Also in the industrial sector of the Vaal River catchment area steps were taken to make a contribution towards maintaining health standards in the Vaal River Barrage. At Sasol researchers and environmental workers introduced comprehensive integrated water management strategies to maintain a high level of dedicated care. ${ }^{54}$ It is believed that these measures, over the long term, would not only reduce surface pollution, but also work towards minimising the threat of toxic substances in the water flowing into the Vaal River.

Recently, local industries have become more active participants in catchment forums in the Vaal River Barrage. ${ }^{55}$ They have also linked up with international initiatives aimed at promoting the sustainable use of water as resource. ${ }^{56}$ The reality of everyday operations in a highly productive industrial sector is however seldom part of an ideal world. In July 2006 there was once again a spate of fish deaths in the Vaal River Barrage. Informed rumours had it that it had been caused by run-off water from the chemical industries, on the Free State side of the Vaal River Barrage. ${ }^{57}$ Claims of this nature have been contested, ${ }^{58}$ but toxic industrial effluent in the sewage water that flowed into the Vaal River was said to have been responsible for the death of large numbers of indigenous mud- and yellow fish that had been mixed with sewage. ${ }^{59}$ Moreover, because some of the sewerage outlets in the Vaal River Barrage catchment flow into the Vaal below the Barrage, pollution of this nature had the effect that fish $150 \mathrm{~km}$ further downstream were also severely affected. ${ }^{60}$

54 Information Martin Ginster, Sasol, 2006.11.06; The Launch of the 2nd Annual Bio2biz Conference. Keynote Address by the Honourable Minister of Science and Technology, Mr Mosibudi Mangena, 2005.10.18, Sandton Convention Centre at http:/ / www.dst.gov.za/media/speeches.php?id=59\&print=1.

55 See Leeu Taaibaschspruit Forum newsletter, issue 1, October 2006, pp. 1-2.

56 Companies in the Vaal Triangle have committed themselves to the recommendations outlined in the World Business Council for Sustainable Development (WBCSD), Business in the world of water: WBCSD water scenarios to 2025, (Atar Roto Presse SA, Switzerland, August 2006).

57 E Tempelhoff, "Vrektes nóg 'n terugslag vir Vaal" in Beeld, 2006.07.26 at http:// 152.111.1.251/argief/berigte/beeld/2006/07/26/B1/5/etvaal.html

58 Comment Martin Ginster, Sasol, 2006.11.06; The research team was given access to a confidential circular of a catchment management group (October 2006). It summarised the findings of an internal investigation into the spillage events by stakeholders in the industrial sector. The information was placed at our disposal after the investigation had been completed.

59 E Tempelhoff, "Vrektes nóg 'n terugslag vir Vaal" in Beeld, 2006.07.26 at http:// 152.111.1.251/argief/berigte/beeld/2006/07/26/B1/5/etvaal.html

60 E Tempelhoff, "Vrektes nóg 'n terugslag vir Vaal" in Beeld, 2006.07.26 at http:// 152.111.1.251/argief/berigte/beeld/2006/07/26/B1/5/etvaal.html 


\section{In search of solutions}

The problems experienced with the pollution of the Vaal River Barrage are by no means an isolated crisis. Worldwide there have been indications of an inability to contend with the demands on the water supply and sanitation systems of urban areas. ${ }^{61}$ In South Africa a number of independent researchers in 2005 embarked on a threeyear regional study of the water resources of South Africa, Lesotho and Swaziland. ${ }^{62}$ The first findings have now emerged in the project, under the auspices of the Water Research Commission of South Africa (WRC), DWAF, in conjunction with academic specialists, consulting engineering firms and the South Africa's Council for Scientific and Industrial Research (CSIR). ${ }^{63}$ In one report dealing with a survey of some 50 wastewater treatment plants in South Africa, it was pointed out:

(T)he majority of micro, small and medium size wastewater treatment plants $\ldots$ are in trouble and do not comply with the regulatory standards. The key aspects to resolve this situation relates to the availability of trained and competent process controllers and skilled mechanical/electrical maintenance crews. ${ }^{64}$

Increasingly there are indications of a shift towards franchising water service operations. ${ }^{65}$ To what extent this strategy is feasible at this point in time, is open to debate. The World Bank has, in recent months become critical of the privatisation of basic services and suggests that these only be considered when there are appropriate forces of competition in the private sector. ${ }^{66}$ In Gauteng there is strong opposition to privatisation. The Anti-Privatisation Forum (APF) was

61 J Rees, "Urban water and sanitation services: an IWRM approach" in TEC Background papers, 11, (Technical Committee (TEC) of the Global Water Partnership, Elanders AB, Sweden, 2006); M Verringer (Reuters), "2. 6 billion people lack access to sanitation - UN" in Plant Ark, 2006.09.29, at http://www.planetark.org/ dailynewsstory.cfm?newsid=38306\&newsdate=29-Sep-2006. Anon., "Three-year water resources study underway" in The Water Wheel, May/ June 2005, p. 5.

63 Anon., "Media release: Prioritising water resource management" (released: 2006.10.09. CSIR web pages at http://www.csir.co.za/plsql/pt10002/ PTL0002_PGE013_MEDIA_REL?MEDIA_RELEASE_NO=7427052

HG Snyman, AM van Niekerk and N Rajasakran, Report summary: Sustainable wastewater treatment - what has gone wrong and how do we get back on track? (Received from the CSIR, October 2006).

$\mathrm{K}$ Wall, Technical note: "An investigation of the franchising option for water services operation in South Africa" in Water SA, 32(2), April 2006, pp. 265-268; Also see the more comprehensive K Wall, Developing a framework for franchising in the water services sector in South Africa, WRC Report No. KV161/05 (Water Research Commission, Pretoria, 2005). 
created in 2000 to contest the privatisation of certain sectors of municipal services rendered in Johannesburg. ${ }^{67}$ Specifically Johannesburg Water, ${ }^{68}$ a privatised sector of the local authority, which has been responsible for the installation of pre-paid water meters in all parts of the city, has been a prime target of activists. ${ }^{69}$ There have been considerable protests and legal actions. There are some interest groups who are of the opinion that the commodification and/or commercialisation of water services could be linked to capitalist strategies aimed at making profits from a resource that should be made available, literally free of charge to society at large. ${ }^{70}$ Of particular concern is the fact that since 2001 a number of initiatives have been introduced by the government to provide free basic services, particularly to the poor in the country. For example, all households are entitled to $6 \mathrm{kl}$ of water monthly, a limited power supply and in some areas of the country, sanitary services. As recently as October 2006 there were reports of incidents of violence and protest at Orange Farm a large informal settlement, situated in the Vaal River Barrage catchment area. The residents, marching under the banner of the 'Orange Farm Water Crisis Committee (OWCC)' have been frustrated by the inability of local political representatives and local government in addressing their essential development requirements. ${ }^{71}$

At the time it was considered to be unlikely that the government would

67 The organisation has subsequently extended its activities to many parts of the country. See "Mosca in Townshipland", (2005.11.22) at

http:/ / townshipsland.blogspot.com/2005/11/anti-privatisation-forumapfwas.html (Accessed 2006.10.20)

68 Johannesburg Water was established in 2001 as an independent company. In an effgort to get funding for its operations and development a five-year management contract was signed with the Johannesburg Water Management Company (JOWAM). It formed a joint venture with Suez Lyonnaise Des Eaux (France), Northumbrian Water (UK) and Water and Sanitation Services (RSA). See Anon., "Our History" onm the website Johannesburg Water: we put the water in your tap, at http:// www.johannesburgwater.co.za/ (Accessed 2006.10.31).

69 Sapa, "Sowetans protest against water meters" in Sunday Times, 2004.09.16 at http://www.sundaytimes.co.za/zones/sundaytimesNEW/newsst/ newsst1095309778.aspx; Anti-Privatisation Form, "Johannesburg Water has declared war on the poor!" on the website Independent Media Centre: South Africa, 2003.09.07 at http://southafrica.indymedia.org/news/2003/09/4496.php (Accessed 2006.10.21).

70 JWN Tempelhoff, "The commodification of water in the arid and semi-arid parts of South Africa: a preliminary historical exploration" in Historia, 50(1), May 2005, pp. 123-146.

71 Anon., "'No peace without development"' on the website Independent Media Centre: South Africa, 2006.10.03 at http://southafrica.indymedia.org/ (Accessed 2006.10.21) 
summarily make available funding for costly long-term improvements to the wastewater and treatment infrastructure in the Vaal River Barrage. ${ }^{72}$ Plans were then made to get government support for improving the infrastructure, ${ }^{73}$ under the auspices of the policy for the Accelerated and Shared Growth in South Africa (ASGISA). ${ }^{74}$ International experience informs us that it is possible to develop sanitation infrastructure in such a manner that impoverished communities can enter into partnerships with local and central governments (and perhaps even private enterprise). By claiming up co-responsibility and co-ownership of valuable infrastructural facilities, communities can form an active part of measures aimed at improving life under conditions of abject poverty. ${ }^{75}$

At this point in time one of the more feasible areas that is pursued is to explore the potential of tourism and also conservation strategies aimed at safeguarding the water environment against unsustainable human activities. The Vaal River Barrage is a popular leisure-time area and holds a lot of promise for development. However, there is a distinct need for closer collaboration between stakeholders to get to a better understanding of the manner in which the potential of the water front can be developed to the maximum. ${ }^{76}$

\section{The legal route?}

The research team contemplated the issue of legal steps. For a number of years the civil society stakeholders in the Vaal River Barrage have made threats of taking legal steps. As part of the research, one member of the team took the initiative to outline a potential legal strategy.

72 Observation by the consulting engineer, Mr F Kolbe, at meeting of the Vergadering Metsi- a-Lekoa steering committee meeting, 29006.08.28.

73 Deliberations that followed proved to be successful. It forms part of a new report currently being completed by the water research group at North-West University.

74 Media briefing document by Deputy President Phumzile Mlambo-Ngcuka, 2006.02.06, "Background document: a Catalyst for Accelerated and Shared Growth - South Africa". Although no specific reference was made in the initial documentation of the government on support for the Vaal River Barrage, there have been indications from a representative of the Gauteng Provincial government, that funds could be generated from this source. Notes taken by author at meeting of the Metsi-a-Lekoa steering committee meeting, Vanderbijlpark, 2006.08.28.

UN-WWAP, UN World water development report 2: water, a shared responsibility, (UNESCO and Berghahn Books, Paris, New York and Oxford 2006), pp. 94-108.

76 Postgraduate research in this field is currently being conducted at North-west University's Vaal Triangle campus, by Mr Y Chamda, a former executive mayor of Vereeniging, and currently advisor to the Mayor's office in the Sedibeng District. 
What follows below, is a summary of a more comprehensive internal report.

Sufficient legislation exists in South Africa to protect the Vaal River Barrage and its biodiversity. ${ }^{77}$ The ideal would be to have the legislation implemented and policed by the relevant spheres of government. At present this is not the case. Water pollution is more than often caused by local authorities. No steps are then taken by the provincial or national spheres of government. The question is: what should be done? An ideal answer is difficult. While a wide array of legal remedies exists, it entails legal action, which is inevitably costly. Therefore concerned citizens and organisations usually shy away from court action and rather use the media to vent their anger and frustration. In terms of the legislation it is possible to lay criminal charges against polluters. This, however, is also not occurring on a regular basis, basically because of the perception that exists that a criminal charge should be laid at a police station, and the police are, in addition to being ill equipped in terms of human resources, not trained in environmental law.

A non-confrontational approach which might be used successfully is to use the tools provided in the National environmental management biodiversity Act, No. 10 of 2004 (NEMBA). It is my suggestion that, with regard to the Vaal River Barrage and its whole catchment area, the following should be done in terms of the NEMBA:

- List wastewater pollution as a threatening process in terms of Section 53;

- $\quad$ List the whole area as an eco-system which is threatened or in need of protection in terms of Section 52(1); and

- $\quad$ Draft a biodiversity management plan for this area as an ecosystem.

In addition, or as an the alternative, the Largemouth Yellow Fish (Labeobarbus Kimberleyensis) which is listed as a vulnerable species by the IUCN and which only occurs in the Vaal and Orange Rivers, should be listed as threatened species and a biodiversity management plan must be drafted for this species.

77 A comprehensive exposition of the potential legislation that can be used to combat the issue of pollution in the Vaal River Barrage, is outlined in a sub-report of the Vaal River Barrage hot spot project (2006-2007). See M Viljoen "Water pollution in the Vaal River Barrage: a legal perspective" (2006.11.02). 


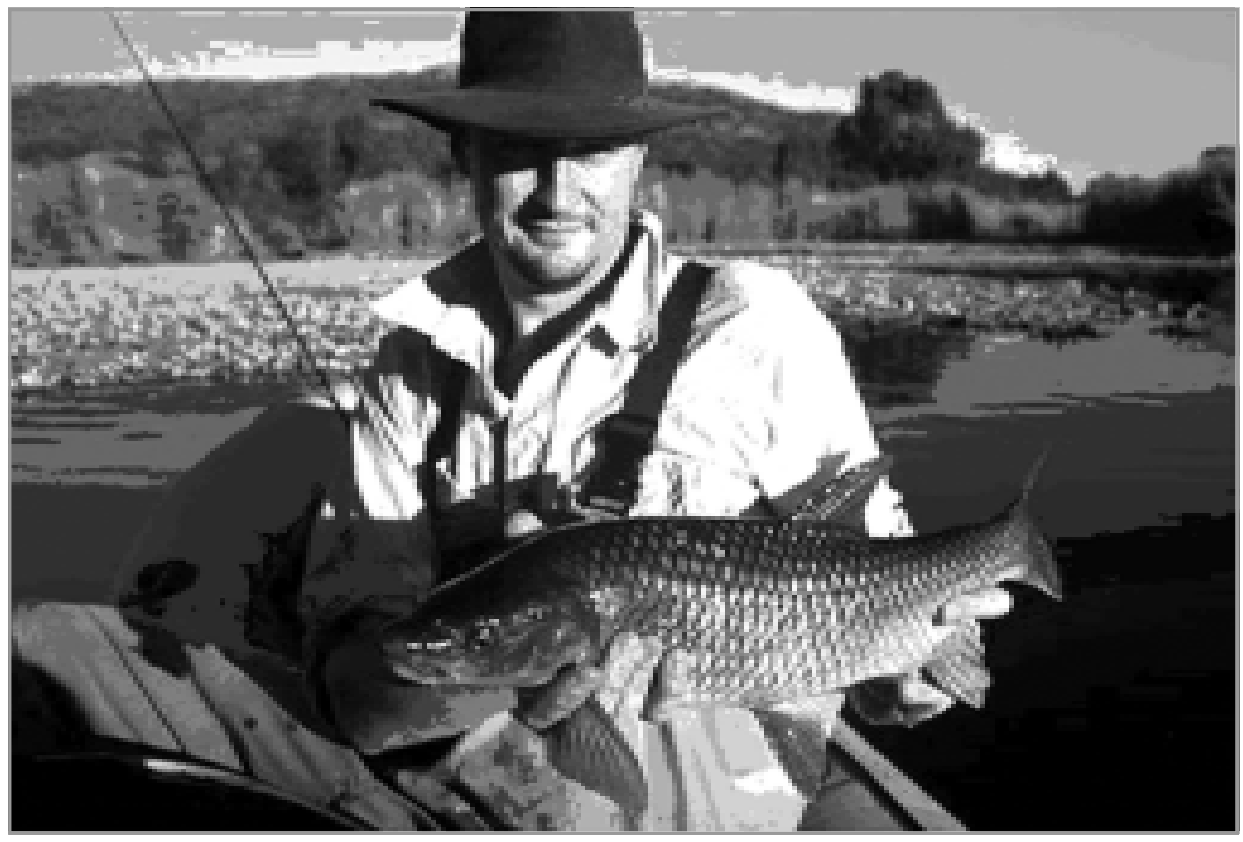

Illustration 8: Fly fisherman, Keith Wallington, with a yellow fish he caught in the Middle Vaal (below the Vaal River Barrage) in the winter season. Once these fish are caught, they are released in the water. ${ }^{78}$

The advantages of this strategy can be summarised as follows:

- It is non-confrontational and would more likely lead to the cooperation of all stakeholders, especially the relevant spheres of government;

- The uncertainty of court cases will be taken out of the equation;

- By proclaiming a species or eco-system as threatened, as well as the publishing of the biodiversity management plan in the Government Gazette, will give such a plan the power of law, in terms of civil enforceability. In addition, the responsible minister can be asked to publish regulations to make the plan enforceable on a criminal basis as well;

- It is holistic and inclusive - all aspects that are a threat to the species or eco-system will be addressed and managed in terms of the management plan, including waste water pollution;

- The associated environment and biodiversity will be at www.yellowsonfly.com/uploads/Middle_Vaal_a_worldclass_fishery_rev_2_ 010404.pdf, p. 3. 
automatically protected;

- Such a plan may be expensive to draft and implement, but one is more likely to obtain funding for the implementation of such a plan, than to obtain funding for litigation;

- A biodiversity management plan must preferably not be implemented by a state organisation, but by an organisation from civil society. This will mean that the management of the eco- system or species will be taken out of the hands of the government and, in fact, they will have to report to the implementing organisation. Thus, a huge load will be relieved from a government under pressure; and

- The whole catchment of the Vaal River Barrage Area should be included, thus encompassing all the sources of pollution.

\section{Conclusion}

Considered from a historical contemplative perspective we have in the Vaal River Barrage a large reservoir that had been built at the beginning of the twentieth century in a river that had been shaped more than 160 million years ago. The human footprint on the banks of the river has left a deep imprint. It is firstly the product of the ever-increasing human demand for water; secondly, the need to dispose of consumed water; thirdly, an awareness that it is essential to have sound measures aimed at conserving the natural environment; and fourthly the need to use the available resources in a sustainable manner.

History also informs us that, as a result of a number of external events - in the form of development over the short- or long-term - the ecology of the Barrage as a man-made storage facility came under threat from time to time. There have always been responses to what was considered to be a threat to the environment. It posed a challenge to the innovative abilities of humans operating in the hydrological sphere, to restore the condition of the water to what was considered to be an appropriate level of health.

In recent times a number of deep structural changes have taken place in the realm of the intellectual culture of South African society. These have had a marked influence on the way in which we currently contemplate the crises facing the Vaal River Barrage.

Firstly, the transition to a democratic dispensation in the country brought about significant shifts in terms of the manner in which industrial technology and facilities were used in the region. For a start, the complex web of cultural infrastructure and activities that had 
been developed for the production of goods and services was subject to revision. What had ostensibly been developed for the benefit of a small portion of the region's population was now stretched to the limit. Provision had to be made for the accommodation of the regional population as a whole. This caused a state of paralysis in the spheres of human cultural production and maintenance.

Secondly, there has been a growing awareness in society, globally and locally, that it is essential to be more sensitive to the natural environment. This has had the effect that civil society has become more overt in its response to threats to the environment. The constitution of South Africa, perhaps one of the most progressive in the world at present, underscores the need to be considerate. The necessary legislation has been approved to take strong measures to maintain law and order in the aquatic realm of the Vaal River Barrage.

Thirdly, there clearly is a need for a commitment on the side of government, the business sector and civil society to seek solutions to effectively address crises. In this respect it appears as if skills of organisational and management dynamics need to be honed. Apart from a new work-ethic, there is also a need for the inculcation of the sense of will - wanting to do something. This is subject to the cultivation of a sense of meaning. If and when the thin membrane between culture and nature is scrutinised more closely, it becomes apparent that there is lots of room for improvement.

Attention needs to be given to:

- Applying an array of cultural devices to promote an appreciation for the aesthetics of natural beauty; and

- Nurturing a sense of altruism when it comes to the realisation that we use our natural resources and we consequently need to invest in their protection;

- Realising that if human culture works towards the restoration of the dignity of nature, the end-result would be the restoration of a human dignity, beyond the ideological and biological constraints of race and creed; and

- Being aware that the condition of the water in the Vaal River Barrage at any given time is a litmus test. It shows to what extent humans are prepared to attach a value to life in the present, with an eye on the future. 